\title{
Anaphylaxis after home-made quinoa dinner: hold the mustard
}

\author{
Lyda Cuervo-Pardo, ${ }^{1}$ Alexei Gonzalez-Estrada, ${ }^{2}$ James Fernandez ${ }^{2}$
}

${ }^{1}$ Department of Internal Medicine, Cleveland Clinic Foundation, Cleveland, Ohio, USA

${ }^{2}$ Department of Allergy and Clinical Immunology, Cleveland Clinic Foundation, Cleveland, Ohio, USA

\section{Correspondence to} Dr Alexei Gonzalez-Estrada, gonzala5@ccf.org

Accepted 13 February 2015
CrossMark

To cite: Cuervo-Pardo L, Gonzalez-Estrada A,

Fernandez J. BMJ Case Rep Published online: [please include Day Month Year] doi:10.1136/bcr-2014208980

\section{DESCRIPTION}

Food is the most common cause of anaphylaxis. ${ }^{1}$ Very few cases of mustard seed-induced anaphylaxis have been reported. We present a case of

mustard seed anaphylaxis. A 29-year-old man presented to our department for evaluation of anaphylaxis. He had an episode of facial flushing and angio-oedema (figure 1), lower extremity urticaria

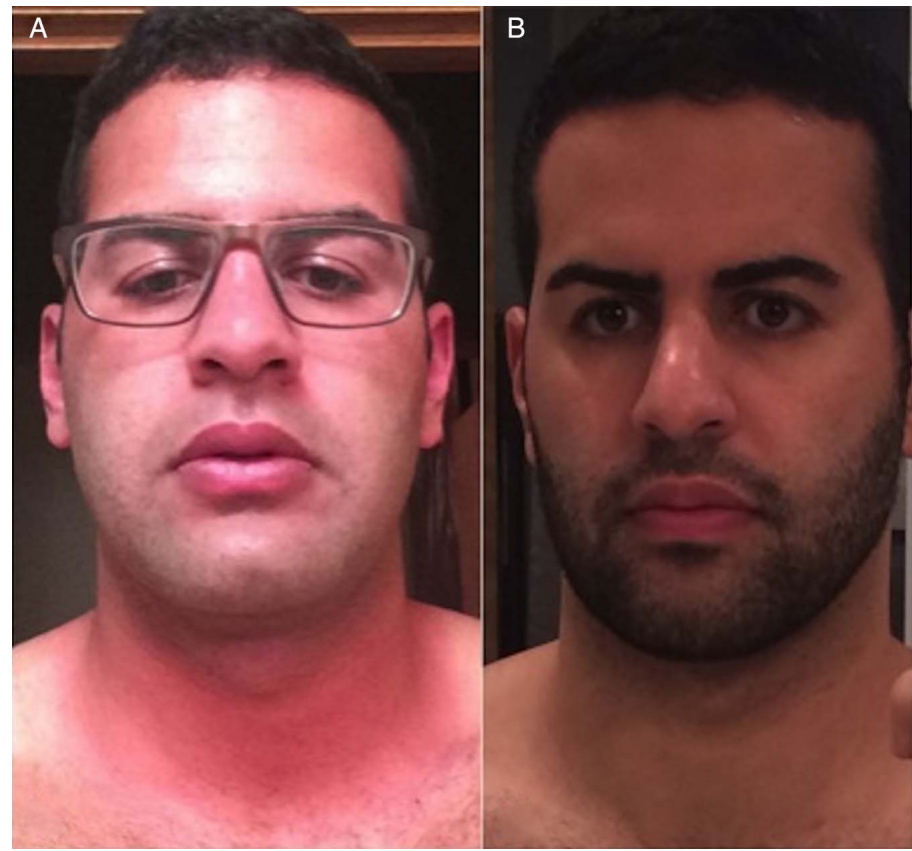

Figure 1 Facial flushing and angio-oedema (A). Patient's face without symptoms (B).

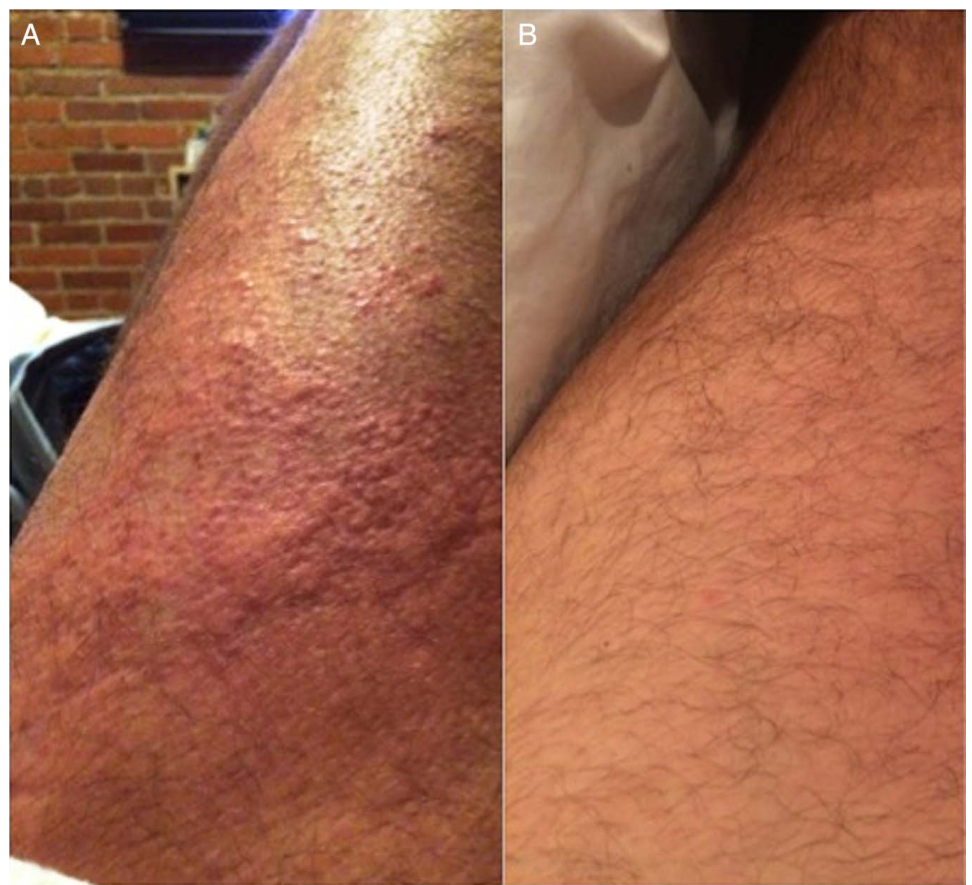

Figure 2 Lower extremity with generalised urticaria (A) and without urticaria (B). 


\section{Learning points}

- Conjunction of careful history and skin testing allowed the identification of the aetiology and establishment of diagnosis of this anaphylactic reaction secondary to mustard seed.

- Despite the widespread use of mustard seed for culinary purposes, food lgE-mediated mustard seed allergy has been considered a rare cause of food allergy, mainly described in Spain, where the biggest case series have been reported. ${ }^{2} 3$

- Mustard seed is frequently used in mustard sauce and seasonings. This may make avoidance challenging for patients.

(figure 2), chest tightness and vomiting within 30 min of eating a prepared quinoa dish at home. He did not seek medical attention and his symptoms resolved within hours of selfadministration of loratadine and diphenhydramine. He had no relevant medical history of previous adverse reactions to foods. On further questioning, the patient revealed the ingredients in the quinoa dish: chicken, rice, avocado, ginger, onion, potatoes, tomato, nutmeg, yeast, soy, wheat, black pepper, thyme and mustard seed. He had previously tolerated quinoa without adverse reactions. However, in this latest preparation, the two last ingredients were obtained from a new brand. His physical examination was unremarkable. Percutaneous skin testing was positive to soy and prick-prick testing to mustard seed. He was instructed on avoidance measures including food label reading and prescribed epinephrine auto injector. This case demonstrates the importance of an adequate clinical history and detailed content of ingredients.

Competing interests None.

Patient consent Obtained.

Provenance and peer review Not commissioned; externally peer reviewed.

\section{REFERENCES}

1 Lieberman P, Nicklas RA, Oppenheimer J, et al. The diagnosis and management of anaphylaxis practice parameter: 2010 update. J Allergy Clin Immunol 2010;126:477-80.

2 Rance F, Duatau G, Abbal M. Mustard allergy in children. Allergy 2000;55:496-500.

3 Caballero T, San Martin MS, Padial MA, et al. Clinical characteristics of patients with mustard hypersensitivity. Ann Allergy Asthma Immunol 2002;89:166-71.

Copyright 2015 BMJ Publishing Group. All rights reserved. For permission to reuse any of this content visit http://group.bmj.com/group/rights-licensing/permissions.

BMJ Case Report Fellows may re-use this article for personal use and teaching without any further permission.

Become a Fellow of BMJ Case Reports today and you can:

- Submit as many cases as you like

- Enjoy fast sympathetic peer review and rapid publication of accepted articles

- Access all the published articles

- Re-use any of the published material for personal use and teaching without further permission

For information on Institutional Fellowships contact consortiasales@bmjgroup.com

Visit casereports.bmj.com for more articles like this and to become a Fellow 